\title{
Food preferences of males and females
}

\section{By A. E. Bender, Department of Nutrition, Queen Elizabeth College, London $W 8 \quad 7 A H$}

Food preferences may be dominated by internal controls (i.e. true sex differences) or by external factors such as fashion, social tradition, custom and taboos that relate to one sex rather than the other. True sex differences should therefore be relatively constant in different communities while external factors may differ at different times and in different communities.

For example 'slimming' obviously affects food choice and, while it is unfashionable for women to be fat in the Western world, the reverse is true in many Eastern countries. Similarly, while some $95 \%$ of members of UK slimming clubs today are women, it was men rather than women who 'slimmed' in Victorian times. One survey (British Market Research Bureau, 1969) reported that 21\% of men and $43 \%$ of women 'had ever slimmed'. Again, while beauty hints may affect the diets of women, strength, sport and muscular development might affect the preferences of men.

Some authorities state that women suffer greater temptations to overeat than men because they are involved in the preparation of food, they sample their own cooking, eat left-overs to save waste, and may eat both with the children and again with their husbands. Boredom and frustration in the home may drive women to overeat as a consolation and they are also said to be less involved in sport and therefore spend less energy in this way than men. Those who have to prepare meals may select convenience foods for reasons other than dietary preference. Finally there are two areas where women's dietary habits might be affected whereas those of men stand aloof, namely pregnancy and motherhood.

On the subject of beauty affecting dietary choice 'The Family Oracle of Health' in 1824 advised women to eat breakfast 'consisting of plain biscuit (not bread), broiled beef steaks or mutton chops, underdone without any fat and half a pint of bottled ale - the genuine Scots is the best. ... Should it be found too strong fare at the commencement, we permit instead of the ale one small breakfast-cup-not more — of good strong black tea or coffee-weak tea or coffee is always bad for the nerves as well as the complexion'. Dinner was to be taken at two o'clock 'the same as for breakfast, no vegetables, boiled meat or made-dishes being permitted, much less fruit, sweet things or pastry... steak and chops must always be the chief' (quoted by Burnett, 1968).

One starting point is popular beliefs, old wives' tales or anecdotal evidence. For example it is commonly held that at the end of the major meal women prefer the sweet while men prefer cheese, that Stilton is a man's cheese, that women prefer 
milk in their coffee in contrast with men, that women prefer sweet liqueurs when men imbibe spirits and that earlier in the meal the women prefer a sweeter wine.

There is very little evidence for or against these beliefs and there is the problem of separating true preferences based on physiological differences from beliefs ingrained in early childhood. Generations of children since 1853 know that the black hen 'laid eggs for gentlemen'; since 1797 it has been taught that the apex of a woman's aspirations is to eat 'strawberries, sugar and cream' ('Curly locks, Curly locks') and that females are given preference for hot-cross buns ('... if your daughter does not like them give them to your sons'). It was a king who ate blackbird pie while his consort ate bread and honey, and one preference dates back to 1639 when it was first reported that Jack Sprat, in contrast with his wife, would eat no dietary lipid. Publication of compositional data, for example that the female is made from 'sugar and spice' might well have led to the variety of habits that we now attempt to untangle.

\section{Sweetness}

A major supplier of sherry reports that as subjects drink more sherry their tastes tend towards the drier varieties. As one moves up the social scale the consumption of sherry increases and the tendency is towards the drier types. However, women cease this tendency before men: in other words women prefer somewhat sweeter sherry than do men.

Sweetness in general, however, is not apparently preferred by women. In one report (Simone, Sherman, Hinreiner \& Valdes, 1956), men, by a small but consistent majority, preferred sweeter samples of canned peaches. A series of 900 males and $\mathrm{r} 360$ females tasted paired samples of different sugar concentrations; in every one of nine sets of pairs more men preferred the sweeter product.

Laird \& Breen (1939), with a much smaller group of subjects, also found that men preferred sweeter pineapple than did women. As in so many of these investigations, the picture is somewhat blurred because not only sweetness but sugar:acid plays a part in preference for fruit.

On the contrary a national survey of the USA (US Department of Health, Education \& Welfare, 1974) showed that men consumed $25 \pm \mathrm{I} \cdot 0 \mathrm{~g}$ sucrose/1000 kcal $(5.97 \pm 0.24 \mathrm{~g} / \mathrm{MJ})$ compared with $33 \pm 2.4 \mathrm{~g}(7.89 \pm 0.57 \mathrm{~g} / \mathrm{MJ})$ for women. Precisely the same values were shown by Guild, Deethardt \& Rust (1972).

So whether or not men prefer sweet foods is not clear, particularly since Amerine, Pangborn \& Roessler (1965) refer to several reports showing that there was no consistent difference when the test foods were canned sweet corn and canned peas with added sugar.

\section{Cheese v. dessert}

Warren (1958) presents some evidence on the problem of cheese $v$. sweet dessert. His values show only a small difference between the sexes: $27 \%$ of men in summer compared with $32 \%$ of women, and $25 \%$ of men in winter compared with $26 \%$ of women, consumed a sweet at the evening main meal. Cheese was eaten by 
$7 \%$ of men compared with $5 \%$ of women in summer, and $6 \%$ of men compared with $5 \%$ of women in winter.

\section{Research results}

There are three experimental approaches to the problem: (I) measurement of taste preferences between offered foods; (2) observation of meals consumed; (3) listing of foods preferred or disliked.

Differences reported in the literature between the sexes are small and inconsistent, numbers of subjects observed are usually small and often menu choice was limited so few clear conclusions can be drawn from most of these reports. Huenemann, Shapiro, Hampton \& Mitchell (r g68) recorded the food eaten by $5 \mathrm{I}$ male and $7 \mathrm{I}$ female students for 2 years and stated that irregularity of eating habits made a long period of observation necessary.

There is not necessarily any relationship between taste thresholds, taste preferences and food selection. Amerine et al. (1965) point out that there is little relation between taste acuity and food acceptance. They report a large difference between men and women in ability to distinguish the four basic tastes $(46.7 \%$ of men and $77.0 \%$ of women), but all differences reported in food preferences were much smaller than this. We (A.E. Bender \& L. Davies, unpublished results) measured taste thresholds for sugar and salt and found that these were not related to preferences for biscuits of differing degrees of sweetness and saltiness. Moreover, the preferences of many individuals for different strengths of these tastes changed when the biscuits were repeatedly sampled over a period of days instead of a simple choice on a single occasion.

Kennedy (1958) examined the likes and dislikes of forty-five college women on a rating scale and compared them with a similar survey on young men. He found no difference between the sexes in foods such as fruits, nuts, cereals, biscuits, dairy produce, pork, poultry, meat, some fish and some cheese. The major difference was that women rated vegetables higher than did men, while men rated potatoes higher than did women. The 'menu of choice' was very similar for the two sexes, with a greater emphasis on salads by the women.

Hall \& Hall (1969) examined the likes and dislikes of $47^{8}$ female and 215 male students by asking them to mark on a given list which foods they disliked so much that they would never eat them. There were three foods that men disliked significantly more than did women, namely (in ranking order), cucumbers 10.7 $v$. 5.9, green peppers $7.9 \mathrm{v} \cdot 2.7$ and tuna fish $7.0 \mathrm{v} . \mathrm{I} \cdot 7$.

On the other hand there were fourteen foods that women disliked more than did men. These included avocado pears, corned beef, beef tongue ( 26 v. I 7 ), beer ( 45 v. 19.5), buttermilk, calves' liver, caviare ( 24 v. $15 \cdot 8$ ), coffee, figs, canned milk, margarine, oysters, rabbit and sweetbreads.

The main reason for dislike was described as taste ( $50.5 \%$ of the answers) while the next reason on the list was texture (only $7 \cdot 2 \%$ ).

These authors conclude that: 'as might be expected from their training and interests women are familiar with a wider assortment of foods than men'. Only 
four foods were known by more men than women (brandy, gin, whiskey and beef liver) while thirteen foods were known by more women.

One point of agreement between the reports of Kennedy (1958) and Hall \& Hall ( 1939 ) was that buttermilk was very much disliked, with men showing the greater dislike in Kennedy's ( $195^{8}$ ) trial.

Table I (Guild et al. 1972) shows the results of a survey of 604 meals selected by American students, calculated as nutrients per $1000 \mathrm{kcal}$. Men consumed more calcium (because they drank more milk), less iron and less ascorbic acid than women; there were little or no differences with fat, protein, carbohydrates, retinol, thiamin, riboflavin or nicotinic acid. Men took a smaller proportion (25\%) of their energy intake at breakfast compared with women (30\%).

Table I. Eating patterns of male and female university students (from Guild, Deethardt \&ீ Rust, 1972)

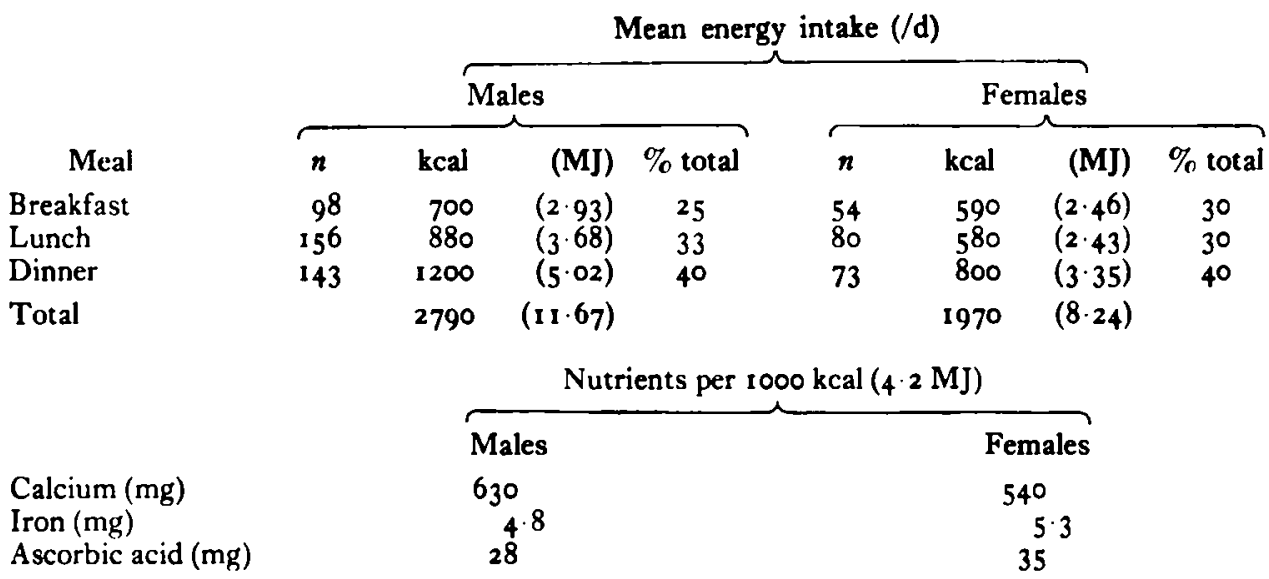

The biggest difference was that men drank on average 4.4 glasses of milk/d compared with 2.4 for women. An odd finding was that men's intake of milk was somewhat greater in autumn while the women's was greater in spring (but numbers were small). Over-all, $9 \mathrm{r} \%$ of the men drank milk compared with $78 \%$ of the women. While this might possiuly be explained on a slimming basis, a survey by the (UK) National Dairy Council (196r) showed that fewer girls accepted school milk in an age-group where slimming was unlikely to have an effect on milk consumption. Stasch, Johnson \& Spangler (1970) confirm the male preference for milk.

Supporting evidence comes from the Nutrition Canada (I973) Survey, where more women had an inadequate $\mathrm{Ca}$ intake than men, a possible cause being a lower milk consumption. As mentioned later, a survey of the USA (US Department of Health, Education and Welfare, 1974), on the contrary, showed the same Ca intake for women and men. 


\section{Breakfast}

One of the most complete of the surveys of dietary patterns carried out in the UK was that of Warren (1958) on the habits of 2100 men and 2400 women. Questions were asked both in summer and winter, so tending to reinforce the findings.

Most differences were quite small. For example $40 \%$ of men in summer and $43 \%$ in winter had early-morning tea compared with 43 and $49 \%$ of women respectively.

There was no difference between the sexes in breakfast eating: men $93 \%$ in summer and $96 \%$ in winter, women $91 \%$ in summer and $94 \%$ in winter. What is surprising is the high numbers taking breakfast compared with more recent values (at least for children) ranging from $30 \%$ in Canada and $24 \%$ in London to $50 \%$ in Hungary (reviewed by Bender, 1974).

There was a marked difference in the types of breakfast eaten, men tending towards the cooked breakfast of eggs and bacon (Table 2). This was confirmed in a more recent survey (British Market Research Bureau, 1975a) showing that men are more likely to have a hot dish at breakfast than housewives, $34 \% v .23 \% ; 20 \%$ of men have bacon $v$. I I \% of women; I $4 \%$ of men have fried eggs $v .7 \%$ of women. This may be due to the feeling that 'the working man needs a good breakfast before starting the day's work' (there was a similar difference in all three social classes).

Table 2. Breakfast consumption by men and women (\%) (from Warren (1958))

$\begin{array}{lccccc} & \overbrace{\text { Summer }}^{\text {Men }} & \text { Winter } & \overbrace{\text { Summer }}^{\text {Women }} & \text { Winter } \\ \text { Total eating breakfast } & 93 & 96 & & 91 & 94 \\ \text { Those eating: } & & 60 & 37 & 41 \\ \quad \text { Cooked course } & 57 & 44 & 26 & 27 \\ \text { Eggs } & 42 & 45 & 42 & 20 & 26\end{array}$

Breakfast cereals offer a good basis for comparison of preferences since they are eaten by three-quarters of the population and have been well researched by the manufacturers (British Market Research Bureau, 1975b).

The first point of interest is that ordinary breakfast cereals (apart from brans and a few special varieties) are eaten to exactly the same extent by males and females. Of a total of twenty-three varieties examined, six were more frequently eaten by children and five by adults but the over-all proportions were the same for males and females. In children there was a slight over-all preference by boys.

The second point is that against a slightly falling market in total breakfast cereals there has been an increase in bran products $(6-7 \%$ of the total in 1964 , 1967 and 1969 , rising to $10 \%$ in 1972 and $11 \%$ in 1974$)$. They are eaten more in the older age group, over 45 years, and much less by adolescents and children. 
These products are greatly preferred by women; of those over the age of 13 years $64 \%$ of the consumers were female. The results are confirmed by the same finding for four different brands of bran products: all showed the ratio, females:males, of 2:I. There is a slight move in the most recent survey towards the younger age group.

There was little or no difference between the sexes in numbers drinking tea $v$. coffee at breakfast (Warren, 1958). Although tea was generally preferred midmorning, women drank more coffee at that time than did men. In the USA, starting from a different base-line, it is reported that more women chose tea than did men (Food Service Marketing, 1973).

In view of the heavy female emphasis on slimming, and the popular views on potatoes, it is surprising that there was no difference in the numbers of subjects eating potatoes at lunch time, although at the evening meal more men ate potatoes than did women: $30 \%$ of men compared with $23 \%$ of women in summer, and $36 \%$ of men compared with $30 \%$ of women in winter (Warren, 1958). This is a small difference in view of the attitude of slimmers towards potatoes.

\section{National surveys}

Two recent surveys throw some light on preferences, those of the Canadian peoples (Nutrition Canada, 1973) and of the USA (US Department of Health, Education and Welfare, 1974).

The survey of the nutritional status of the Canadian population was carried out between 1970 and 1972 on 15000 people $(24 \mathrm{~h}$ recall and frequency of consumption of certain foods over the previous month). While the interpretation of the data and standards established for clinical, biochemical and dietary abnormalities are open to argument, the dietary intakes at least allow comparison between males and females.

Table 3. Dietary evaluation of Canadians in the age-group 20-39 years (percentage with inadequate intake) (from Nutrition Canada, 1973)

\begin{tabular}{|c|c|c|c|c|c|c|}
\hline & \multicolumn{2}{|c|}{ General population } & \multicolumn{2}{|c|}{ Indians } & \multicolumn{2}{|c|}{ Eskimos } \\
\hline & Male & Female & Male & Female & Male & Female \\
\hline $\begin{array}{l}\text { Protein } \\
\text { Iron }\end{array}$ & $\begin{array}{l}2 \\
4\end{array}$ & $\begin{array}{r}9 \\
38\end{array}$ & 4 & $\begin{array}{l}10 \\
42\end{array}$ & $\begin{array}{l}0 \\
0\end{array}$ & $\begin{array}{r}8 \\
28\end{array}$ \\
\hline Calcium & 9 & 19 & 17 & 41 & 15 & 45 \\
\hline Vitamin A & 14 & 24 & 26 & 45 & 46 & 85 \\
\hline Ascorbic acid & 4 & 6 & 6 & II & 24 & 22 \\
\hline Thiamin & 8 & 12 & 9 & 20 & I & 29 \\
\hline
\end{tabular}

The summary in Table 3 compares the sexes (as well as two population subgroups) expressing the results as a percentage of subjects with an inadequate nutrient intake. Some nutrients are based on recommended daily intakes (RDI) expressed per kg body-weight and so are a reflection of the types of food eaten as 


\section{Vol. 35 Sex differences in response to nutritional variables}

well as quality, namely $\mathrm{Ca}$, vitamin $\mathrm{D}$ and ascorbic acid; $\mathrm{Fe}$ is in a special category since the RDI for females is $15 \mathrm{mg}$ and that for males is $10 \mathrm{mg}$, while RDI for other nutrients is the same for both sexes.

In every instance there were more females consuming a poorer diet. Females appear to take less protein than males in young and mature adults and in all three ethnic groups. Similarly the $\mathrm{Ca}$ intake is less in females. The fact that more women have an inadequate diet indicates either that their total food intake is low or that the quality of the diet (nutrients as a proportion of the energy) is low. If the former is true then there is no evidence from these values whether the choice of foods differs, but if the latter is true then the females must be consuming different types of food from the males. Less Ca would tend to mean less dairy foods; less retinol with a somewhat similar ascorbic acid intake could also be explained by lower intake of milk.

The survey of the United States population was carried out in $1971-2$ (24 h recall). Table 4 shows the dietary intakes of white subjects only, aged 18-44 years, of all income groups. The energy intakes differ considerably and the nutrient intakes are expressed in relation to energy. Protein, $\mathrm{Fe}$ and $\mathrm{Ca}$ intakes are very close but the women consume about $30 \%$ more vitamin $A$ and $38 \%$ more ascorbic acid than men.

Table 4. Mean daily intake of energy and nutrients by the white population, 18-44 years old, of the USA (from US Department of Health, Education and Welfare, 1974)

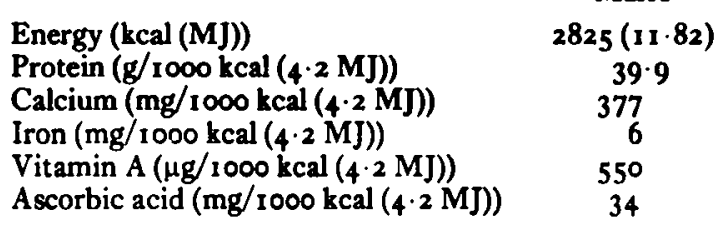

$\begin{array}{cc}\text { Males } & \text { Females } \\ 2825(11 \cdot 82) & 1670(6 \cdot 99) \\ 39 \cdot 9 & 40 \cdot 6 \\ 377 & 380 \\ 6 & 6 \cdot 3 \\ 550 & 720 \\ 34 & 47\end{array}$

Some possible deductions can be made about foods eaten. The similar values for $\mathrm{Ca}$ intake suggest, contrary to previously quoted values, that milk consumption is about the same. The higher intakes of vitamin A therefore would not come from milk but, together with higher ascorbic acid, suggest the likelihood that women eat more vegetables.

These values differ from the Canadian ones where women appear to be consuming less foods supplying vitamin $A$ and ascorbic acid, as well as less of all the nutrients listed, even bearing in mind that the USA values are expressed per Iooo kcal while the Canadian values are a proportion of the RDI.

There are so many well established regional, ethnic, traditional, economic and other factors that affect food choice that it is difficult to decide whether conclusions drawn from national averages are a more reliable indicator of sex differences than those drawn from smaller experimental groups. 


\section{Knowledge of nutrition}

It is very debatable whether a knowledge of nutrition has any effect on eating habits. McKenzie \& Yudkin (1963) found that domestic science students showed 'considerable inability to apply their nutritional knowledge'. Today anyone with some knowledge of nutrition might select polyunsaturated fats, reduce sucrose intake, increase dietary fibre, fruits and vegetables, take vitamin concentrates as an added insurance, and even eat less food than his or her less-informed colleagues.

On this basis women should differ from men in their preferences since they are better informed on the subject. It is girls rather than boys who have for the last 100 years been receiving some basic school instruction in domestic science, and one survey at least showed that women knew more about 'food values' than men (British Market Research Bureau, 1969). A system of marking awareness of vitamins showed an arbitrary score of $29 \%$ for females and $18 \%$ for males. The more children in the home the better informed were their mothers (score for housewives without children $26 \%$, with one or two children $32 \%$, with three or more children $38 \%$ ). In parallel, $41 \%$ of women felt able to offer advice on nutrition compared with $29 \%$ of men.

The evidence from which to draw conclusions of sex differences in food preference is scanty. Foods eaten are determined by a very large number of recognized factors but opportunity to make a particular selection is itself controlled by many factors. It has been established that foods purchased for home consumption by the housewife are more strongly influenced by the husband's preferences than those of the housewife or the children, although the husband has the least knowledge of nutrition (British Market Research Bureau, 1969). In that survey one-third of the housewives questioned thought that their children's tastes were influenced by their parents' preferences, with father's likes outweighing those of the mother by II $\%$ to $6 \%$. Parents' dislikes had relatively little effect, $4 \%$ and $3 \%$ respectively for mothers' and fathers'.

Among the less obvious reasons for selecting foods are the position on the refectory counter and the visibility. Levitz (1975) states that closing the lid of the ice-cream freezer resulted in a $70 \%$ reduction in uptake of ice-cream (by both obese and slim).

\section{Conclusions}

It is uncertain whether there are any clear differences in food preferences between the sexes. There are several contradictions in the literature. Schuck ( $\mathrm{I} 96 \mathrm{I}$ ) stated that women have a greater preference for fruit, whereas Huenemann et al. (1968) found that men ate a little more vegetables and fruits than women. Several reports have been quoted of differences that Knickrehm, Cotner \& Kendrick (1 969) failed to find; and the USA and Canadian surveys appear to be contradictory as regards sex differences. Amerine et al. (1965) state that the differences in sensory acuity and likes and dislikes of foods are usually more pronounced between people of the same sex than between the two sexes as groups. They conclude from a number of surveys that women are more consistent in their opinions than men. 
Martin (I 973) states that most studies on tasting panels have found that sex, age up to 50 years and smoking habits had little influence on the individual's ability to discriminate taste.

We might hope that preferences of children, untrammelled by tradition and advertising, might throw some light on this subject but Breckenridge ( 1959) stated that there is no sex difference in the likes and dislikes of 5-12-year-old children, in contradiction of findings of Tussing (1939), who stated that boys had more likes and girls had more dislikes.

One of the few relatively firm conclusions that come from the scattered literature is that women have a greater preference for fruit (Schuck, 196r), a lesser preference for milk and a more adventurous palate, and that more men eat a cooked breakfast, at least in the UK.

I am grateful to the Kellogg Company of Great Britain for allowing me access to their findings on breakfast-cereal consumption studies.

\section{REFERENCES}

Amerine, M. A., Pangborn, R. M. \& Roessler, E. B. (1965). Principles of Sensory Evaluation of Food, p. 404. New York: Academic Press.

Bender, A. E. (1974). Proc. Nutr. Soc. 33, 45.

Breckenridge, M. E. (1959). F. Am. diet. Ass. 35, 704 .

British Market Research Bureau (1969). Food Facts and Fallacies. BMRB/RHS/42850. London: British Market Research Bureau.

British Market Research Bureau (1975a). National Menu Survey: Winter. London: British Market Rescarch Bureau.

British Market Research Bureau (1975b). Cereal Consumption Study, 1974. London: British Market Research Bureau.

Burnett, J. (Ig68). Plenty and Want: a Social History of Diet in England from $181_{5}$ to the Present Day. London: Penguin Books Ltd.

Food Service Marketing (1973). J. Am. diet. Ass. 63, 688 Abstr.

Guild, L., Deethardt, D. \& Rust, E. (1972). F. Am. diet. Ass. 61, $3^{8}$.

Hall, I. S. \& Hall, C. S. (1939). F. Am. diet. Ass. 15, 540.

Huenemann, R. L., Shapiro, L. R., Hampton, M. C. \& Mitchell, B. W. (1968). F. Am. diet. Ass. 53,17 .

Kennedy, B. M. (1958). F. Am. diet. Ass. 34, $50 \mathrm{r}$.

Knickrehm, M. E., Cotner, C. G. \& Kendrick, J. G. (1969). J. Am. diet. Ass. 55, 117.

Laird, D. A. \& Breen, W. J. (1939). F. Am. diet. Ass. 15, 549.

Levitz, L. (1975). In Obesity: its Pathogenesis and Management [J. T. Silverstone, editor]. London: Medical and Technical Publiahing Co. Ltd.

McKenzie, J. C. \& Yudkin, J. (I963). Proc. Nutr. Soc. 22, xoxi.

Martin, S. L. (1973). Fd Technol., Champaign 27(11), 22.

National Dairy Council (1961). Milk Drinking in Schools. London: National Dairy Council.

Nutrition Canada (1973). Nutrition Canada: National Survey. Ottawa: Canadian Ministry of National Health and Welfare.

Schuck, C. (1961). F. Am. diet. Ass. 39, 595 .

Simone, M., Sherman, L., Hinreiner, E. \& Valdes, R. M. (1956). Fd Technol., Champaign 10, 279.

Stasch, A. R., Johnson, M. M. \& Spangler, G. J. (1970). J. Am. diet. Ass. 57, 523.

Tussing, L. (1939). Proc. Indian Acad. Sci. 48, 198.

US Department of Health, Education and Welfare (1974). First Health and Nutrition Examination Survey, United States 197I-1972. Washington, DC: Health Resources Administration National Centre for Health Statistics.

Warren, G. C. (1958). The Foods We Eat. London: Cassell. 